\title{
ICT Usages in Yogyakarta's Tourist Villages Development
}

\author{
Ulfah Choirunnisa ${ }^{*}$, Rini Rachmawati \\ Urban Development Research Group, Department of Development Geography, Faculty of Geography, Universitas \\ Gadjah Mada
}

\begin{abstract}
Developmental gap between tourist villages occurs due to differences in tourist attractions, existing facilities, and also the use of Information, Communication, and Technology (ICT). One of the innovations which is presently in line with global development is the use of information technology. This study was aimed at identifying the development of 17 tourist villages using the Butler Tourist Area Life Cycle Theory, determining the use and needs of ICT in tourist villages using the Smart Tourism Destinations Theory, and analyzing the role of ICT in developing tourist villages in the City of Yogyakarta. The results of this study indicated that the dynamics of the development of tourist villages were caused by several factors: availability of human resources, the potential of tourist villages, and tourism awareness of tourist village communities. Besides, the use of ICT in the villages was limited to wi-fi usage and the use of social media such as Facebook and Instagram. Lastly, the role of ICT actively by managers and passively by tourists was able to accelerate the development of tourist villages.
\end{abstract}

Keywords: ICT, Tourist villages.

\section{INTRODUCTION}

Several tourist villages in Yogyakarta have been well developed. For example, Dipowinatan is often visited by Czech tourists. Same as Cokrodiningratan, which attracts Japanese tourists and Purbayan, which attracts USA tourists. One of the indicators used to measure the intelligence level of tourist villages is the accessibility of information [1].

The developmental gap between tourist villages occurs due to differences in tourist attractions and existing facilities. One of the innovations which are presently in line with global development is the use of information technology. It includes information systems, internet, information technology, communication, computer software, networks, along with the hardware. The function of hardware is to process, to send information supported by its following software and also networks [2].

Efforts to evolve tourist villages through the use of information technology are in line with various forms of promotional support and information stipulated in Yogyakarta Mayor Regulation number 115 of 2016 article 15 verse(2) word (f). One of Yogyakarta's tourism sector opportunities is the development of information technology and social media [3].

Tourist village has an attraction that could attract people to come, getting entertained, and

*Correspondence address:

Ulfah Choirunnisa

Email : ulfahc@outlook.com

Address : Bulaksumur, Caturtunggal, Kec. Depok Kab. Sleman, Daerah Istimewa Yogyakarta 55281 got unique experiences [4]. The important criteria to build a positive relationship between tourism and culture are: 1) Having a routine cultural performance, 2) Participating local community and for additional, participating tourists, 3) Be able to create product/service needed by tourists, and 4) Be able to gain profit from cultural performance [5].

The development of tourist villages could be analyzed by using the Tourist Area Life Cycle theory by Butler. It was explained that there are seven phases of development: Exploration, Involvement, Development, Consolidation, Stagnation, Decline, and Rejuvenation.

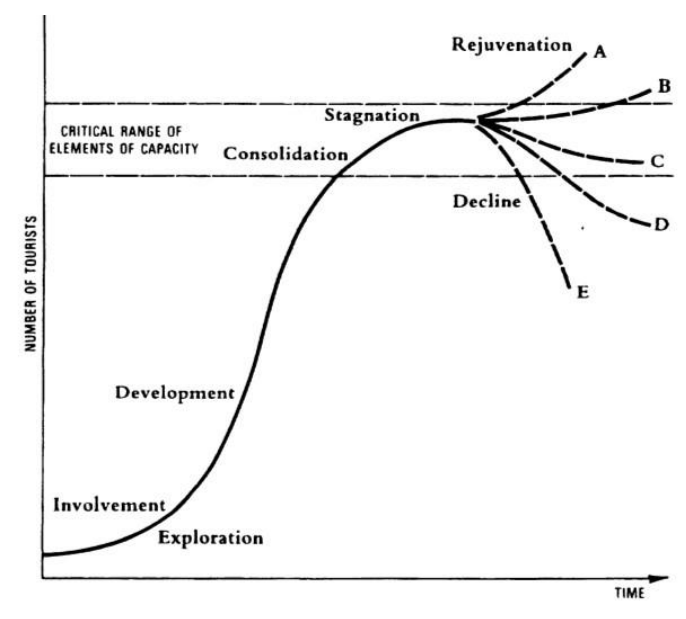

Figure 1. TALC Curve (Source: ijier.net)

Tourism destinations should have supported by 4 main components called ' $4 A^{\prime}$ '. It refers to Attraction, Amenities, Access, and Ancillary services including ICT [6]. 
ICT is a group of technology along with the applications related to an electronic process, storage, and information transfer for various forms of usage [7]. Independent tourism emerged from the synergic relation among stakeholders by technology platform where tourism activities can be instantly given and received [8]. Smart Tourism Destinations made use of 1) Technology embedded environment (Internet of Things, sensors), 2) Responsive processes at micro and macro levels (Intelligent services), 3) End-user devices (Smartphones), and 4) Engaged stakeholders that use the actively use platform to gain information [8]. Smart Tourism Destinations into two categories: 1) SoftSMARTness: collaboration, innovation, leadership (human resources) and 2) HardSMARTness: technology and infrastructures (the heart of smartness) [9].

The development of ICT usages in several countries started from 1970-2007 [7]. Yogyakarta, in 2005, has begun to use the internet and ATM [7]. Then, in 2007, in the same city, the use of ICT facilities and internet cafés were developed [7]. One of the previous researches related to ICT showed that villages managed by using ICT were more flexible against industrial changes and could adjust better [10]. The higher the level of ICT's utilization, the faster industrial changes occur. ICT is also one of the determinants that need to be considered in choosing housing locations. Research showed that $55 \%$ respondent chose to move on housing location where provides ICT facilities [11]. Besides, ICT also affects economy and movement space changes [12]. From the dynamics of population mobility and the dynamics of the location of economic services, it could be concluded that the future city structure will be determined by ICT usages in various types of activities that shorten travel distance and time [13]. This study was aimed at identifying the development of 17 tourist villages using the Butler Tourist Area Life Cycle Theory, determining the use and needs of Information, Communication, and Technology (ICT) in tourist villages using the Smart Tourism Destinations Theory and analyzing the role of ICT in developing tourist villages in the City of Yogyakarta.

\section{MATERIAL AND METHOD}

This study used qualitative research. A literature review was done by reviewing the previous researches, government policies, related books, and other valid data sources. The observation was done in 17 Yogyakarta's tourist villages by observing either the physical characteristic or social activities. An in-depth interview was done to the 17 managers of tourist villages, which will be clearly explained below.

\section{Data Collection}

The in-depth interview technique for each manager in 17 tourist villages was accomplished to disclose its development in a chronological descriptive manner. Three of 17 tourist villages had chosen as the samples in identifying the use and needs of ICT was adopting a purposive sampling technique with criteria for the level of search for tourist villages on the internet: very low, average, very high, so does the unique development. Furthermore, the researcher also conducted independent observation through the internet to obtain additional information regarding the use of ICT and the development of tourist villages in Yogyakarta.

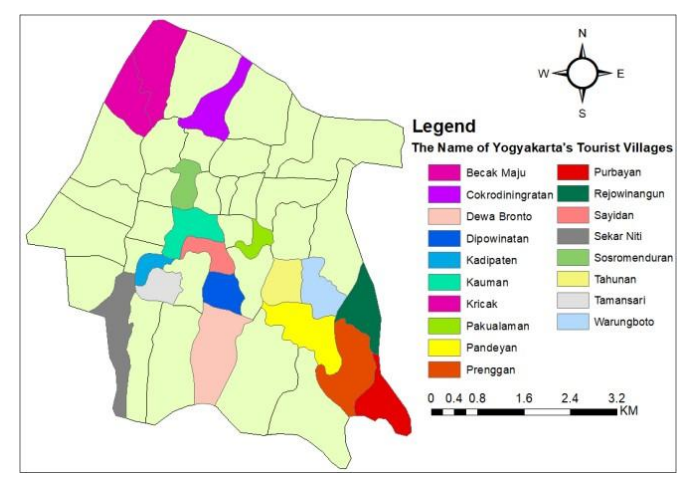

Figure 2. Research Location Map (Source: Yogyakarta Municipal Department of Tourism, 2017)

\section{Data Analysis}

This research was using descriptive analysis. It is to show the data and to explain the tourist village development chronologically.

\section{RESULT AND DISCUSSION \\ Tourist villages Development}

The development of The Tamansari Tourist Village has been in the phase of consolidation. It was indicated by the number of tourists who have reached the peak, so that, the quota has set to 500.000 tourists each year, and tourist who came in above $4 \mathrm{pm}$ in each day was forbidden. It was set to avoid public inconvenience. It also indicated by the rise of the craft trade scale (it has already gone international), and the more facilities, accommodations, transportation, and other complementary, needs to be provided. However, tourists who used the accommodation facilities were not the only tourist who aimed to 
visit Tamansari Tourist Village only. Most of them were tourists who were on the Yogyakarta city tour but looking for the cheap inn and near the city center. The arrival of this visitor despite helping village promotion, but on the other hand, this indicated that the value of tourist villages was fade away because the culture was no longer attracts tourists.

Kadipaten tourist village still in the exploration phase where there were no economic opportunities, either tourism package or its unique product. Besides, the number of tourists could not be predicted even monthly. It was too small. It has happened too in the Kauman tourist village. Cokrodiningratan tourist villages have been in the involvement phase which indicated by the emerging of company supports in facilities development, facilities provided by its local community, profit gained by local community from their facilities providing. Sosromenduran tourist village was in the development phase. It was indicated by the emerging of investors and has been known by their promotion either offline or online.

Dewa Bronto, Sayidan, Sekar Niti, and Pakualaman tourist villages were the same in the involvement phase. Local community has started to provide accomodation facilities and restaurant. The increasing of tourists occurs on holiday.

Becak Maju tourist village still in the exploration phase. It was occurred because of no economic opportunities available, either a tourism package or a unique product. Tahunan, Rejowinangun, and Prenggan tourist villages have been in the development phase, which has been known by people either from offline or online media. The trade scale has already raised to international, and they improve their village's promotion.

Dipowinatan tourist village has been in the consolidation phase. It was indicated by the wider promotion they did and the emerging of the competitor. Warungboto tourist village has been the most developed village among the 16 others. The phase of development has been in the highest one, which is the rejuvenation phase. Rejuvenation phase indicated by making new alternative attractions. This village has developed three phases at the same time in just three months only. Whereas, one last village, Pandeyan, experienced an anomaly development because it didn't experience sequent phase per phase. But it directly collapses from the exploration phase to the decline phase. The decline phase is the lowest phase where tourist villages couldn't compete with the surroundings, quality service decreasing, and it was affected by the function of its tourist village. People was not having pride anymore toward their tourist village because they didn't have any feeling through the function of it, especially from the economy side. The visualization of the development phase for each tourist village showed in the Figure 3 and 4.

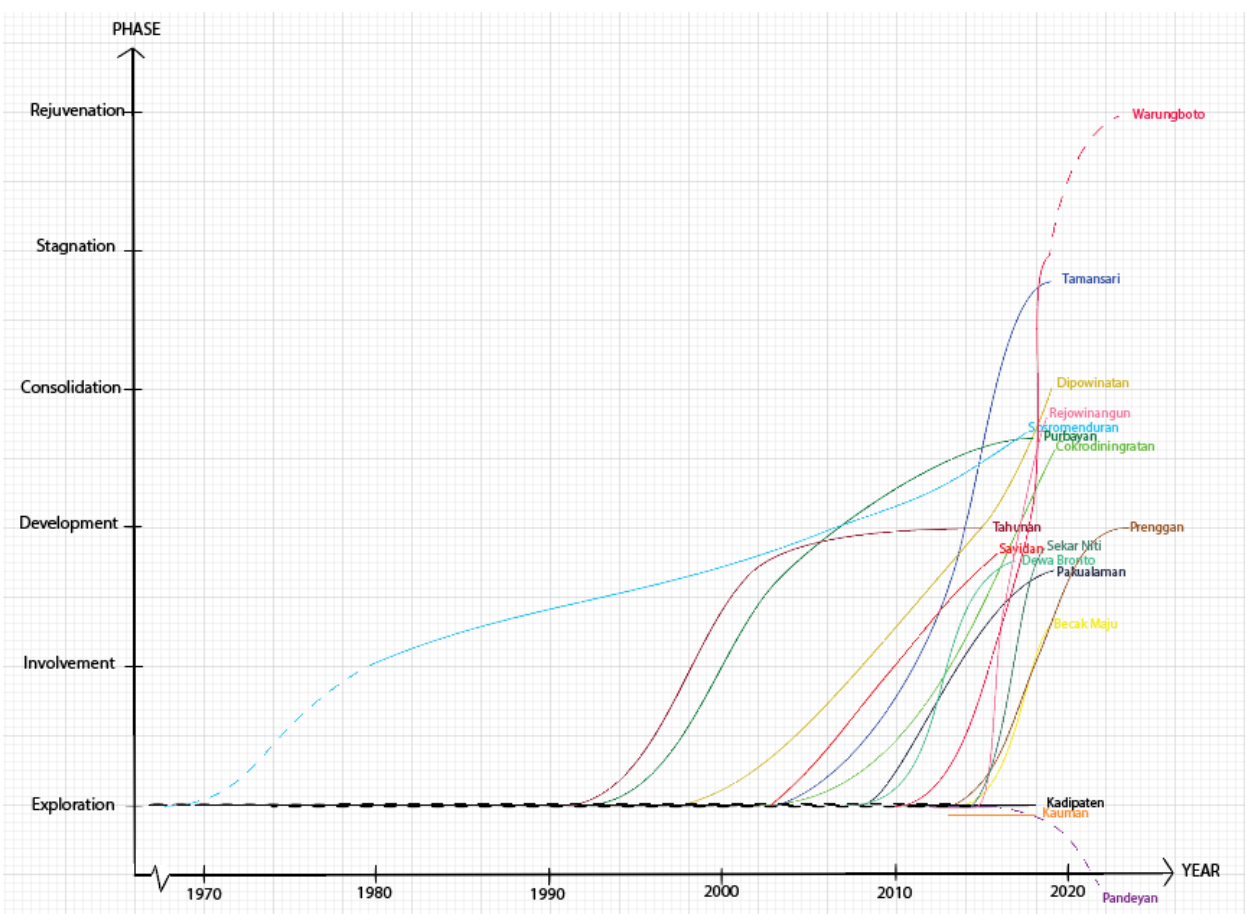

Figure 3. The Curve of Yogyakarta's Tourist villages Development Phase (Source: Data Analysis, 2019) 


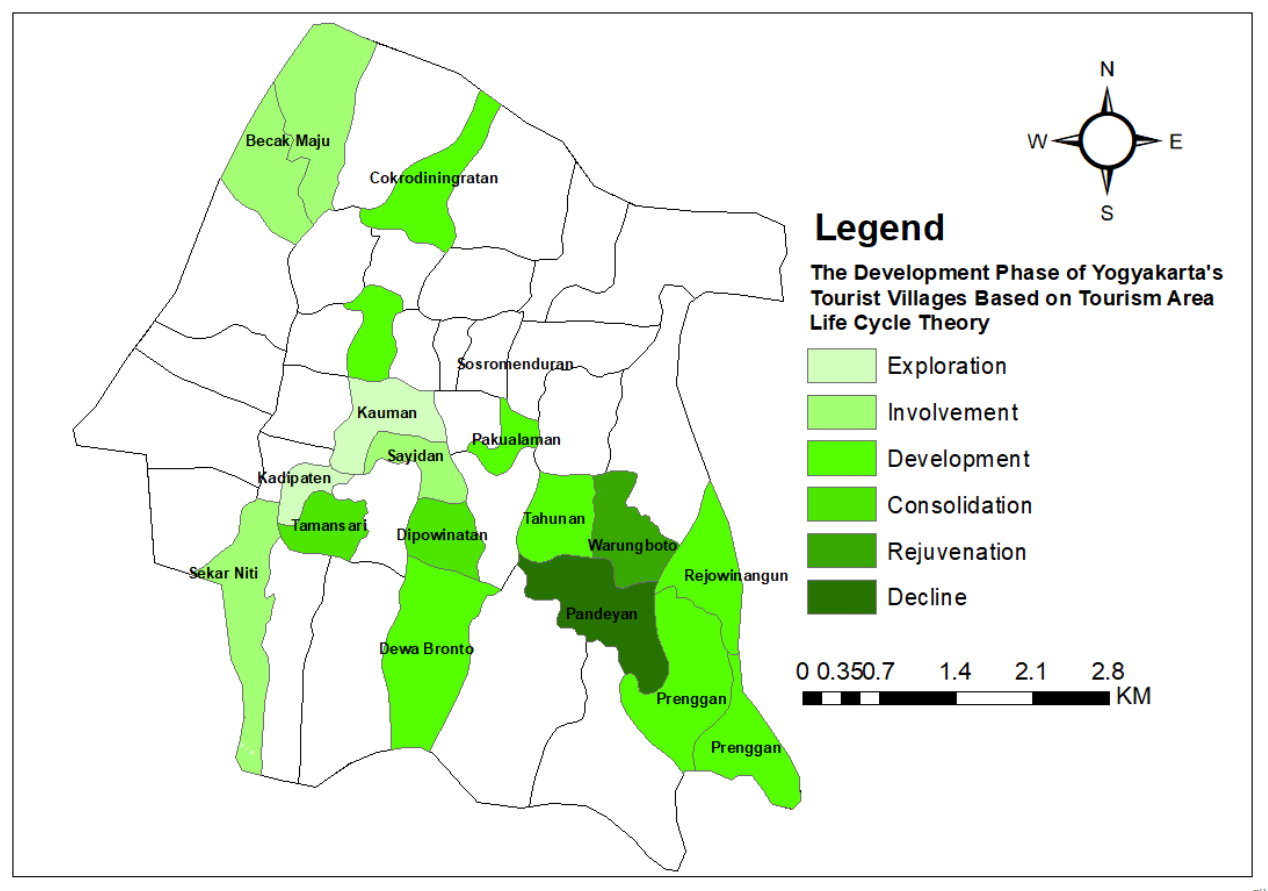

Figure 4. Yogyakarta's Tourist villages Development Phase Distribution Map (Source: Data Analysis, 2019)

\section{ICT Usages and Needs}

ICT usage and needs in the development of tourist villages measured from HardSmartness (hardware) and SoftSmartness (software) aspects. Hardware are including Wi-Fi, NFC, AR, and APP(s) for 'technology embedded environment' indicator and 'End-user' hardwares such as smartphones and laptops. Meanwhile, softsmartness could be applications, social media, and other various forms of activities that improving expertise on the use of ICT [8]. All 17 tourist village managers have used smartphones. Only one from four hardware has been provided by governance for a tourist village. The hardware is Wi-Fi. Fourteen tourist villages have been facilitated Wi-Fi by Yogyakarta Governance. The other three were still waiting for the Wi-Fi installation (Fig. 5).

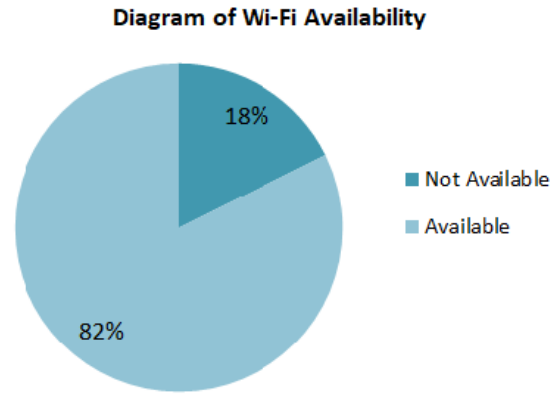

Figure 5. The Diagram of Yogyakarta's Tourist villages WiFi Availability (Source: Field Survey, 2019)
NFC hasn't been installed in tourist villages to be used for ticketing or other transaction. It because tourist villages were not a one-gatetourism destination. Tourists could enter tourist villages from any gate they found without any fee. Hardware used in tourist villages is a smartphone, laptop, and Wi-Fi. Smartphone has become primary hardware owned by each tourist village managers. This hardware used for receiving the reservation of tourism package, selling products/services, and receiving critics and suggestions from tourists.

The use of softsmartness includes ICT softwares, networks, and human resources. ICT software, in this case, were smartphone applications like WhatsApp and google maps. Meanwhile, social media networks were limited to Facebook, Instagram, Youtube, and Blog/ Website. Five tourist villages (29\%), has 3 of 3 social media which are Website, Facebook, and Instagram. Three tourist villages (18\%) have 2 of 3 social media, seven tourist villages only have 1 social media, and the other 2 tourist villages have any. The number of tourist villages searches based on its name on the internet also observed by www.brand24.com. It is a site that could count how many does the keyword search in the current time. In this research, the time set is May 17, 2019, to June 17, 2019. 
Table 1. Number of Tourist villages Search name as a Keyword Search

\begin{tabular}{lrrrrrr}
\hline Village & Facebook & Instagram & Blog & Youtube & Website & Total \\
\hline Tamansari & 79 & $\mathbf{2 0 4 2}$ & $\mathbf{9 5 6}$ & $\mathbf{2 6}$ & $\mathbf{2 6 5}$ & $\mathbf{3 3 6 8}$ \\
Kauman & $\mathbf{1 3 9}$ & 202 & 142 & 0 & $\mathbf{2 1 4}$ & 697 \\
Kadipaten & 58 & 197 & 144 & 30 & 92 & 521 \\
Pakualaman & 10 & 124 & 291 & 21 & 71 & 517 \\
Warungboto & 3 & 191 & 13 & 29 & 8 & 244 \\
Rejowinangun & 19 & 88 & 14 & 31 & 17 & 169 \\
Sayidan & 8 & 69 & 17 & $\mathbf{4 0}$ & 26 & 160 \\
Purbayan & 6 & 90 & 10 & 0 & 22 & 128 \\
Pandeyan & 15 & 58 & 29 & 7 & 13 & 122 \\
Sekar Niti & 3 & 89 & 3 & 3 & 2 & 100 \\
Bener & 13 & 18 & 11 & 11 & 13 & 66 \\
Kricak & 13 & 18 & 11 & 11 & 13 & 66 \\
DewaBronto & 2 & 16 & 11 & 1 & 14 & 44 \\
Prenggan & 16 & 6 & 2 & 7 & 36 \\
Sosromenduran & 5 & 4 & 7 & 0 & 9 & 25 \\
Cokrodiningratan & 5 & 13 & 5 & 1 & 5 & 24 \\
Dipowinatan & 0 & 1 & 3 & 3 & 14 & 21 \\
Tahunan & 0 & 0 & 0 & 0 & 0 & 0 \\
\hline Source: brand24.com & 0 & & & & \\
\hline
\end{tabular}

Source: brand24.com, 2019.

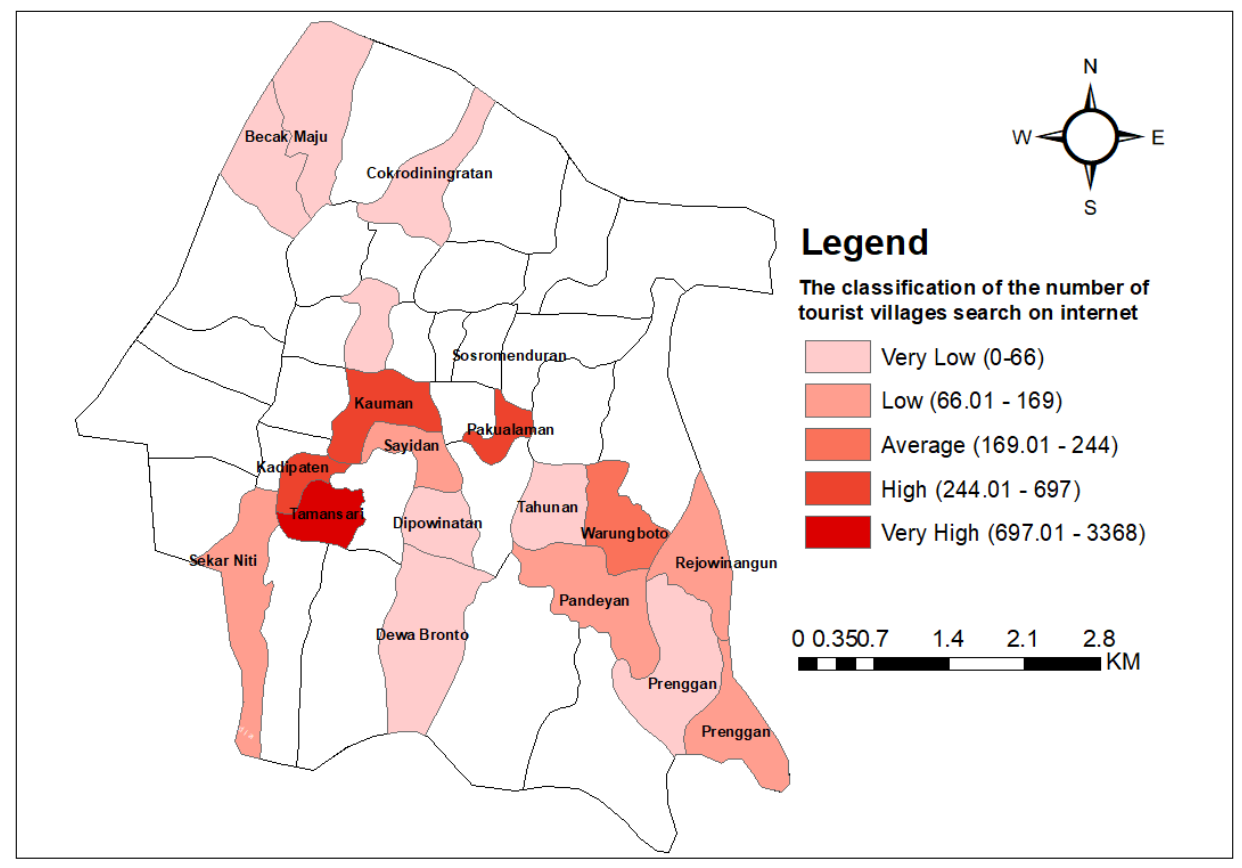

Figure 7. Map of the Level of Mention of Tourist Villages on the Internet (Source: Data Analysis based on brand24.com, 2019)

The table 1 above shows the number of tourist villages keyword searches. Within a month (May 17 to June 17, 2019), the most discussed tourist village is Tamansari: 3368 words search. The tourist village that most discussed on Facebook was Kauman: 139 words. Then, the most tourist village discussed on the Instagram, blog, and website was Tamansari: 2042, 956, 265. The most discussed on Youtube was Sayidan: 40. Last, the most discussed tourist villages on the website are Tamansari and Kauman (265 and 214 discussed).
The other ICT usage is the use of WhatsApp messenger. It used to connect government and intervillage tourist village managers by communication forum virtual group. This virtual group became the main promotion of all the tourist villages. Then, google maps, as one of the most applications installed on tourist village managers are used to drive tourists to come to the tourist villages. Social media that widely used by all of the tourist village managers are Instagram and website. But, not all of them were active. Figure 7 is a map of the search level of tourist villages based on the brand24 site. 
Samples selected from the lowest, average, and highest class. Those are Dipowinatan, Warungboto, and Tamansari, respectively.

Dipowinatan has Facebook, Instagram, and website accounts. But the website is inactive. Tamansari and Warungboto both have Facebook and Instagram accounts. Warungboto's Facebook account is active, while both of Tamansari's accounts are inactive.

The needs of ICT devices have been felt enough by all tourist villages in Yogyakarta It turned out because most of the tourist villages have been facilitated with $\mathrm{Wi}-\mathrm{Fi}$ by the government, although it hasn't been massively utilized. A matter that needed now is ICT socialization, especially for the SMEs perpetrator. This socialization is needed for doing online marketing.

The needs of online marketing also felt by other tourist villages as the findings in the study toward Village Development Movement (Gerakan Desa Membangun - GDM). This program was established since the critics toward the top-down development where the village's role as an object, not a subject. GDM is a program related to social, economic, cultural, political, and technology aspects. There, villages trained to stand by their selves by improving villages management, including the ICT usages such as websites for their local products [14]. This finding was also similar to research on the Jambearum tourist village. The findings showed that the SME's had promoted their product by SMS, gethok tular, exhibition, brochures, but very few people have used the internet as s marketing media. So they wanted the website that contains all of the products of all SME's there [15].

This research about ICT usages in tourist villages development was giving the same result as two previous researches that people have not used the internet well for promoting their product and attraction. Besides villages, ICT has been a factor in choosing housing [11]. People were tending to choose in a housing that provides ICT facilities [11]. It explained that ICT was the main factor. Further than that, in the urbanization era, ICT has changed people's behaviors such as the changing shopping methods (from offline to online), changing working methods (remote working by teleconference), and communicating methods [16]. It concluded that ICT would make a change in the economic and mobility space [12]. So, it was a need for the tourist village's local community to get embedded with ICT due to face globalization and develop their villages.

\section{The Role of ICT in Developing the Selected} Tourist villages

The role of ICT in developing tourist villages divided into two categories: active from tourist village managers and passive from tourists. Tamansari tourist village tends to the passive role through their tourist who shared their photos after visiting Tamansari on Instagram. Individual observation through hashtags search on Instagram has done to find out how many posts shown. Through hashtag '\#tamansari', it found out 224669 photos (June 22, 2019) uploaded by tourists. Meanwhile, Tamansari's Instagram and Facebook accounts were inactive.

Warungboto tourist village has a typical attraction as Tamansari. But, Warungboto's visit is still free. Individual observation through hashtags searches '\#situswarungboto' found out 9266 photos (June $22^{\text {nd }}, 2019$ ). It was 480 numbers above the previous one on April $26^{\text {th }}$, 2019. Tamansari and Warungboto have a differentiation related to the role of ICT. Warungboto could balance the role, both passive and active, to raise their tourist village's promotion. Meanwhile, Tamansari mostly tends to a passive role.

Dipowinatan tourist village has a small number of searches on the internet based on brand24. Social media they owned were also inactive. It turned out that the target of tourists is the Czech tourist. The customer of their tourism package was only from international tourist, especially Czech. This focused tourist market target effects on the services provided. ICT's role as the strategy to promote their tourist villages is still limited. They prefer using a repeater, someone whose origin was in Dipowinatan, but now is living in Czech and doing promotion from people to people.

\section{CONCLUSION}

The dynamics of the development of tourist villages were caused by several factors, including the availability of human resources, which are the driving force, the potential of tourist villages, and tourism awareness of tourist village communities. The use of ICT in the villages was limited to Wi-Fi usage and the use of social media such as Facebook and Instagram. The role of ICT actively by managers and passively by tourists was able to accelerate the development of tourist villages. 


\section{REFERENCES}

[1] Wiyatiningsih. 2016. Smart Tourism Kampung di Yogyakarta. Jurnal Penelitian BAPPEDA Kota Yogyakarta 12, 88-96.

[2] Onn, C. W., and S. Sorooshian. 2013. Mini literature analysis on information technology definition. Information and Knowledge Management 3(2), 139-140.

[3] Syakdiah. 2017. Dinamika pariwisata Daerah Istimewa Yogyakarta. Proceeding of Seminar and Call For Paper $20^{\text {th }}-21^{\text {st }}$ October 2017. Faculty of Social and Political Sciences, Muhammadiyah University of Sidoarjo, Indonesia.

[4] Sihombing, A., J. Gunawijaya, S. A. Zanny, and A. Pratiwi. 2016. Sustainable tourism in rural area development, case study: Kampung Tourism in Wanayasa, Purwakarta, West Java, Indonesia. Journal of Tourism, Hospitality and Sports 15, 16-22.

[5] Organisation for Economic Co-operation and Development. 2005. Culture and local development. OECD Publishing. Paris.

[6] Suwena, I. K., and I. G. N. Widyatmaja. 2010. Pengetahuan dasar ilmu pariwisata. Analisis Pariwisata, 58-72.

[7] Rachmawati, R. 2014. Pengembangan Perkotaan dalam Era Teknologi Informasi, dan Komunikasi. Gadjah Mada University Press. Yogyakarta.

[8] Buhalis, D., and A. Amaranggana. 2013. Smart tourism destinations. Springer international publishing. Switzerland.

[9] Beemt, W. P. d, dan Smith, R. 2012. Smart Tourism Tools: Linking Technology to The Touristic Resources of A City

[10] Moinnemati, A. H. 2015. The roles of information and communication technology on rural development. Global Journal of Human Science: H Interdisciplinary 15(2), Version 1.0 2015. Global Journals Inc. USA.

[11] Rachmawati, R., R. Rijanta, and A. Djunaedi. 2015. Location decentralization due to the use of information and communication technology: Empirical evidence from Yogyakarta, Indonesia. Human Geographies 9(1), 5-15.

[12] Rachmawati, R. 2011. Perubahan pola spasial pergerakan penduduk dan lokasi pelayanan ekonomi yang tersubstitusi oleh teknologi informasi dan komunikasi (studi kasus: perkotaan Yogyakarta). PhD Thesis. Graduate School, Gadjah Mada University. Yogyakarta.
[13] Rachmawati, R. 2012. Population mobility and urban spatial structure: does the use of nformation and communication technology matter? Regional Views 25, 9-19.

[14] Badri, M. 2016. Pembangunan pedesaan berbasis teknologi informasi dan komunikasi (studi pada gerakan desa membangun). Jurnal RISALAH 27(2), 62-73.

[15] Arbainah, S. 2014. Pemasaran bersama berbasis ICT sebagai media promosi alternatif bagi UMKM desa wisata. Jurnal Akuntansi Bisnis dan Perbankan Indonesia 22(2), 180-187.

[16] Rachmawati, R. 2016. Urbanization in the era of Information and Communcation Technology (ICT). Proceeding of the $13^{\text {th }}$ International Asian Urbanization Conference. Rapid Urbanization and Sustainable Development in Asia. Study Program of Regional Development, Faculty of Geography. Gajah Mada University. Yogyakarta, 6-8 Januari 2016. 281-290. 